\title{
Pengembangan Modul Pembelajaran Biologi Berbasis Jelajah Alam Sekitar (JAS) Materi Ekosistem Taman Nasional Kelimutu (TNK) SMA Kelas X
}

\author{
Kristina Novita Ule ${ }^{1 *}$, Yohanes Nong Bunga ${ }^{1}$, Yohanes Bare ${ }^{1}$ \\ ${ }^{1}$ Program Studi Pendidikan Biologi, Fakultas Keguruan dan Ilmu Pendidikan, Universitas Nusa \\ Nipa, Indonesia
}

*Email: cristynaule250@gmail.com

\begin{tabular}{|c|c|}
\hline Info Artikel & Abstrak \\
\hline $\begin{array}{l}\text { Diterima: } 30 \text { Desember } 2020 \\
\text { Direvisi: } 26 \text { September } 2021 \\
\text { Diterima } \\
\text { untuk diterbitkan: } 28 \text { Oktober } \\
2021\end{array}$ & $\begin{array}{l}\text { Penelitian ini memiliki tujuan untuk mengembangkan modul } \\
\text { yang valid dan efektif dalam pembelajaran biologi melalui } \\
\text { Jelajah Alam Sekitar (JAS) pada materi ekosistem Taman } \\
\text { Nasional Kelimutu (TNK) untuk siswa kelas X SMA. } \\
\text { Penelitian ini merupakan penelitian pengembangan dengan }\end{array}$ \\
\hline $\begin{array}{l}\text { Keywords: } \\
\text { 4D, } \\
\text { Ekosistem, } \\
\text { Jelajah Alam Sekitar, } \\
\text { Modul pembelajaran } \\
\text { TNK }\end{array}$ & $\begin{array}{l}\text { menggunakan model 4-D. Ada } 4 \text { tahap dalam penelitian ini, } \\
\text { yaitu tahap pendefinisian (define), perancangan (design), } \\
\text { pengembangan (develop), dan penyebaran (desseminate). } \\
\text { Tempat pengambilan data untuk pengembangan modul di } \\
\text { Taman Nasional Kelimutu di Kabupaten Ende. Subjek } \\
\text { penelitian adalah siswa/i kelas X SMA Negeri } 1 \text { Nita yang } \\
\text { berjumlah } 34 \text { orang. Instrumen penelitian yang digunakan } \\
\text { adalah wawancara, angket, observasi, dan dokumentasi. Produk } \\
\text { hasil pengembangan (modul) divalidasi oleh para ahli media, } \\
\text { ahli materi, dan ahli bahasa yang selanjutnya diujicobakan pada } \\
\text { skala kecil dan skala besar yakni } 3 \text { orang guru dan } 34 \text { peserta } \\
\text { didik. Hasilnya menunjukkan baik dari ahli maupun uji skala } \\
\text { kecil. Uji skala besar mengategorikan modul dalam kondisi } \\
\text { valid. Keefektifan produk yang dikembangkan diperoleh dari } \\
\text { tes hasil belajar peserta didik. Berdasarkan hasil dari validator, } \\
\text { guru, dan peserta didik disimpulkan bahwa modul yang } \\
\text { dikembangkan layak digunakan dan setelah diujicoba } \\
\text { keefektifan modul memenuhi kategori cukup efektif. Hasil } \\
\text { pengembangan modul dapat diaplikasikan dalam pembelajaran } \\
\text { karena memiliki nilai valid dengan nilai kelayakan yang layak } \\
\text { digunakan. }\end{array}$ \\
\hline
\end{tabular}

(C) 2021 Universitas Bengkulu. This is an open-access article under the CC-BY license (https://creativecommons.org/licenses/by/4.0) 


\section{PENDAHULUAN}

Pendidikan memiliki makna sebagai proses yang mempengaruhi peserta didik untuk mampu beradaptasi dengan lingkungannya. Peran pendidikan adalah meningkatkan sumber daya manusia (SDM) yang unggul dalam upaya meningkatkan kualitas pendidikan secara nasional dan internasional dalam upaya menghadapi persaingan global (Hamalik, 2013; \& Bare, 2019). Salah satu upaya pengembangan dalam bidang pendidikan ditandai dengan penggunaan berbagai metode secara bervariasi yang sesuai dengan karakteristik materi, karakteristik peserta didik, dan fasilitas yang ada dalam pembelajaran. Pembelajaran merupakan suatu rangkaian kegiatan yang dirancang dan dikembangkan dengan tujuan untuk membantu proses belajar melalui bantuan yang diberikan oleh guru sehingga dapat membantu peserta didik memperoleh ilmu dan pengetahuan, penguasaan kecakapan, pembentukan sikap, dan kepribadian peserta didik (Hardianto, 2012). Peningkatan mutu pendidikan di Indonesia dilakukan dengan menerapkan kurikulum 2013 yang menekankan pada proses pembelajaran yang interaktif, inspiratif, dan menantang peserta didik untuk berpartisipasi aktif. Dalam rangka meningkatkan mutu pendidikan diperlukan sumber belajar yang memadai. Sumber belajar didefinisikan sebagai sesuatu yang dapat dimanfaatkan oleh guru, baik secara terpisah maupun dalam bentuk gabungan untuk kepentingan belajar mengajar untuk meningkatakan efektifitas dan efisiensi sesuai dengan tujuan pembelajaran (Hamdani, 2010).

Potensi lokal yang ada di lingkungan sekitar siswa perlu dimanfaatkan untuk mengintegrasikan pembelajaran biologi sehingga siswa dapat menggali, mengembangkan, memahami, dan menghadapi berbagai potensi lokal yang ada. Di sekolah, proses pembelajaran biologi sebagai upaya guru untuk meningkatkan kualitas sumber daya manusia (SDM) biasanya tidak terlepas dari penggunaan buku teks yang disediakan oleh sekolah. Ada beberapa topik dalam buku teks yang harus dipelajari siswa untuk meningkatkan kemampuannya. Untuk membimbing siswa belajar mandiri, guru dituntut untuk mengembangkan bahan ajar yang sesuai dengan karakteristik sekolahnya. Secara garis besar, buku teks berisi pengetahuan, keterampilan, dan sikap, dan siswa harus mempelajari pengetahuan, keterampilan, dan sikap tersebut untuk mencapai standar kemampuan yang telah ditentukan.

Upaya pengembangan bahan ajar berupa modul, guru harus lebih kreatif dalam mendesain inovasi pembelajaran agar menarik bagi peserta didik dalam proses pembelajaran. Menurut Renat et al., (2017) modul ini merupakan salah satu buku teks yang semenarik mungkin berdasarkan indikator dan tujuan pembelajaran, serta menggunakan bahasa yang mudah dipahami, dan digunakan siswa secara mandiri. Pembelajaran menggunakan modul dapat meningkatkan motivasi peserta didik dan hasil belajar.

Pemanfaatan berbagai potensi yang ada di lingkungan sekitar tentunya membuat peserta didik tidak hanya memahami modul secara teori, tetapi juga mengintegrasikan dengan potensi lokal, sehingga lebih aplikatif dan peduli pada lingkungan sekitar sekolah (Hamidah \& Ratnasari 2020; Jayanti et al., 2017). Salah satu materi biologi yang selaras dengan pendekatan atau memanfaatkan lingkungan sekitar adalah materi tentang ekosistem. Ciri-ciri material ekosistem, yang membahas tentang hubungan atau interaksi organisme dengan lingkungan. Penjabaran materi ekosistem pada Kompetensi Dasar 3.10 yaitu menganalisis komponen-komponen ekosistem, interaksi, dan interaksi antar komponen tesebut.

Materi ekosistem dipelajari dengan memanfaatkan lingkungan sebagai obyek nyata yang terdapat di sekitar lingkungan peserta didik. Misalnya dengan menunjukan komponen-komponen penyusun ekosistem baik yang berupa makhluk hidup, maupun yang tidak hidup. Dengan demikian, peserta didik akan lebih memahami materi yang diajarkan. Sebagai contoh, pemanfaatan Taman Nasional Kelimutu sebagai sumber belajar masih minim dilakukan, padahal Taman Nasional Kelimutu memiliki potensi alam yang dapat dimanfaatkan dalam mendukung kegiatan pembelajaran. Selain keunikan fenomena alam, Taman Nasional Kelimutu dilengkapi dengan kekhasan ekosistem di sekitarnya, dimana terdapat tanaman Vaccinym varingiaefolium dan Rhododenron renchianun yang merupakan salah satu flora endemik di kawasan Taman Nasional Kelimutu. Pengelompokkan dari beberapa jenis flora pada satu tempat di sekitar kawasan juga 
dapat dijadikan sebagai sumber genetik dan pengembangan riset, serta pendidikan yang saat ini dirancang menjadi arboretum atau tempat koleksi tanaman.

Berdasarkan hasil observasi dan wawancara dengan peserta didik di SMAN 1 Nita, peserta didik menyatakan bahwa proses pembelajaran biologi materi ekosistem masih berpusat pada guru, sehingga peserta didik cenderung pasif pada saat pembelajaran. Pada saat pembelajaran di kelas, peserta didik hanya menggunakan sumber belajar yang disiapkan di sekolah sehingga peserta didik merasa jenuh dalam pembelajaran, serta guru menggunakan metode konvensional (ceramah, diskusi, dan tanya jawab) dalam proses pembelajaran. Solusi yang diperlukan untuk menyelesaikan permasalahan tersebut adalah perlu dikembangkan modul pembelajaran biologi berbasis penjelajahan lingkungan sekitar untuk meningkatkan motivasi belajar siswa dan membantu siswa lebih aktif, kreatif, dan mudah dalam belajar. Penerapan pembelajaran berbasis eksplorasi alam (JAS) merupakan metode pembelajaran yang menekankan pada pemanfaatan lingkungan alam (termasuk lingkungan fisik, sosial, dan budaya) di sekitar kehidupan siswa sebagai objek pembelajaran biologi, dan fenomena biologi dipelajari melalui karya ilmiah (Santoso et al., 2017). Marianti (2016) menjelaskan bahwa yang menjadi karakteristik kegiatan pembelajaran metode penjelajahan lingkungan selalu berhubungan langsung dengan lingkungan alam atau secara tidak langsung, yaitu melalui penggunaan media. Tujuan penelitian adalah menganalisis kelayakan dan keefektifan modul pembelajaran materi ekosistem Taman Nasional Kelimutu.

\section{METODE}

Penelitian ini terbagi menjadi dua bagian, bagian pertama pengambilan data pengembangan modul di Taman Nasional Kelimutu (TNK) di Kabupaten Ende dan pengujian keefektifan dilaksanakan di kelas X SMA Negeri 1 Nita, Kabupaten Sikka, Provinsi Nusa tenggara Timur. Penelitian ini berlangsung selama 4 bulan terhitung Agustus-Desember 2020. Metode penelitian yang digunakan adalah Penelitian dan Pengembangan (R\&D). Metode Penelitian dan Pengembangan adalah metode yang digunakan untuk menghasilkan produk tertentu dan uji keefektifan produk (Sugiyono 2012, 2013).

Teknik pengumpulan data sangat terkait dengan kegiatan pengukuran (measurement). Pengumpulan data dalam pengembangan modul pembelajaran biologi berbasis Jelajah Alam Sekitar (JAS) menggunakan teknik non tes berupa angket, wawancara, observasi, dan dokumentasi. Kualitas modul pembelajaran biologi yang diperoleh dari pengisian lembaran penilaian oleh tiga dosen ahli dimuat dalam bentuk tabel kelayakan produk dan saran perbaikan. Penentuan skor validasi menggunakan skala Likert dengan skala 5 (Admadianti, 2016). Uji efektivitas dilakukan dengan memberikan soal pretest dan post test. Uji hasil pretest dan post test dengan ujian menggunakan gain score.

\section{HASIL DAN PEMBAHASAN}

Hasil yang diperoleh dalam penelitian dan pengembangan ini berupa modul biologi melalui pendekatan Jelajah Alam Sekitar (JAS) pada materi ekosistem kelas X SMA.

\section{Pengembangan Produk Awal}

Hasil penelitian pengembangan modul berbasis Jelajah Alam Sekitar, berdasarkan metode penelitian yang dilakukan adalah sebagai berikut:

Tahap Pendefinisian (define)

Tahap awal dalam penelitian ini bertujuan untuk menetapkan dan mendefinisikan syaratsyarat pengembangan. Berikut penjabaran hasil dari penelitian pada tahap pendefinisian:

Analisis Awal

Analisis awal yang dilakukan adalah melakukan wawancara dengan peserta didik di SMAN 1 Nita yang bertujuan untuk mengetahui kondisi peserta didik, buku panduan yang digunakan dalam proses pembelajaran, serta gambaran kegiatan pembelajaran biologi yang berkaitan dengan penelitian pengembangan yang dilaksanakan. Rencana pengembangan modul ini didasarkan karena sumber belajar dan media belajar yang kurang di sekolah terkhusus di 
SMA Negeri 1 Nita. Sumber belajar yang digunakan masih berupa buku paket yang tidak bersinggungan langsung dengan kehidupan masyarakat yang berbasis kearifan lokal. Lingkungan tempat tinggal juga memiliki sumber belajar yang sepadan yang dapat dijadikan sebagai satu kajian pembelajaran kontekstual.

Analisis Peserta Didik

Tahap ini dilakukan untuk menelaah karakteristik peserta didik yang meliputi, latar belakang pengetahuan, perkembangan kognitif, dan pengalaman belajar peserta didik. Penggunaan modul pembelajaran biologi ini ditujukan kepada peserta didik kelas X MIA1 tahun pelajaran 2020/2021 dengan jumlah 32 orang. Latar belakang peserta didik lebih memahami konsep mengenai materi masih dalam kategori menghafal sehingga sangat sulit untuk dilakukan pengukuran, serta pemahaman peserta didik. Oleh karena itu, perlu dilakukan pengembangan modul yang berbasis kearifan lokal sehingga peserta didik diajak untuk belajar secara kontekstual di alam sekitar sambil memahami materi biologi.

Analisis Materi

Materi yang digunakan dalam pengembangan modul pembelajaran biologi berbasis Jelajah Alam Sekitar (JAS) adalah materi ekosistem yang meliputi komponen-komponen ekosistem, interaksi antar komponen, dan aliran energi. Kajian materi ini meliputi hubungan atau interaksi organisme dengan lingkungan. Penjabaran materi ekosistem pada Kompetensi Dasar 3.10, yaitu menganalisis komponen-komponen ekosistem, interaksi, dan interaksi antar komponen tesebut.

Tahap Perancangan (design)

Tahap ini merupakan tahap dalam melakukan perancangan produk yang akan dikembangkan, yaitu:

Penyusunan Instrumen

Tahap ini menggunakan angket serta soal pretest dan post test untuk mengukur keberhasilan dan efektivitas modul JAS yang telah dikembangkan dan akan digunakan dalam proses pembelajaran.

Pemilihan Media

Pemilihan media dilakukan untuk mengidentifikasi media pembelajaran yang relevan dengan karakteristik materi. Artinya, pemilihan media dilakukan untuk mengoptimalkan penggunaan bahan ajar pada pembelajaran di kelas. Media yang digunakan dalam pelaksanaan pembelajaran biologi dengan pendekatan Jelajah Alam Sekitar (JAS) pada materi ekosistem di kelas $\mathrm{X}$ adalah modul yang dikembangkan oleh peneliti dengan mengadopsi beberapa buku referensi.

Pemilihan Format

Format yang digunakan berupa buku bahan ajar modul materi ekosistem. Pemilihan format dalam pengembangan modul pembelajaran meliputi lembar kegiatan peserta didik yang dibuat semenarik mungkin dan dilengkapi dengan komponen-komponen pelengkap, gambar, soal-soal diskusi, dan soal evaluasi agar peserta didik tertarik dan termotivasi belajar. Sehingga dapat menambah pengetahuan peserta didik lebih luas dan juga dapat meningkatkan hasil belajar peserta didik.

Rancangan Awal

Pengembangan modul biologi dengan pendekatan Jelajah Alam Sekitar pada materi ekosistem untuk siswa kelas X SMA didasari bahan ajar yang digunakan masih berupa buku cetak yang terbatas jumlahnya.

\section{Hasil Validasi Ahli dan Revisi Produk 1}

Nilai yang diperoleh dari aspek materi 4,66 dengan kategori sangat valid. Ahli media bertugas memvalidasi aspek media. Nilai yang diperoleh dari aspek media adalah 4,50 dimana nilai tersebut berada pada kategori sangat valid. Ahli bahasa bertugas memvalidasi aspek bahasa. Dimana nilai yang diperoleh dari aspek bahasa adalah 4,11 dan nilai tersebut berada pada kategori valid. Perhitungan validasi menggunakan rumus rerata skor dengan jumlah raters (penilai) 
sebanyak 6 ahli (Gambar 1). Hasil validasi kesimpulan dari tiga orang validator rata-rata menyatakan bahwa media yang dikembangkan dapat digunakan dengan sedikit revisi.

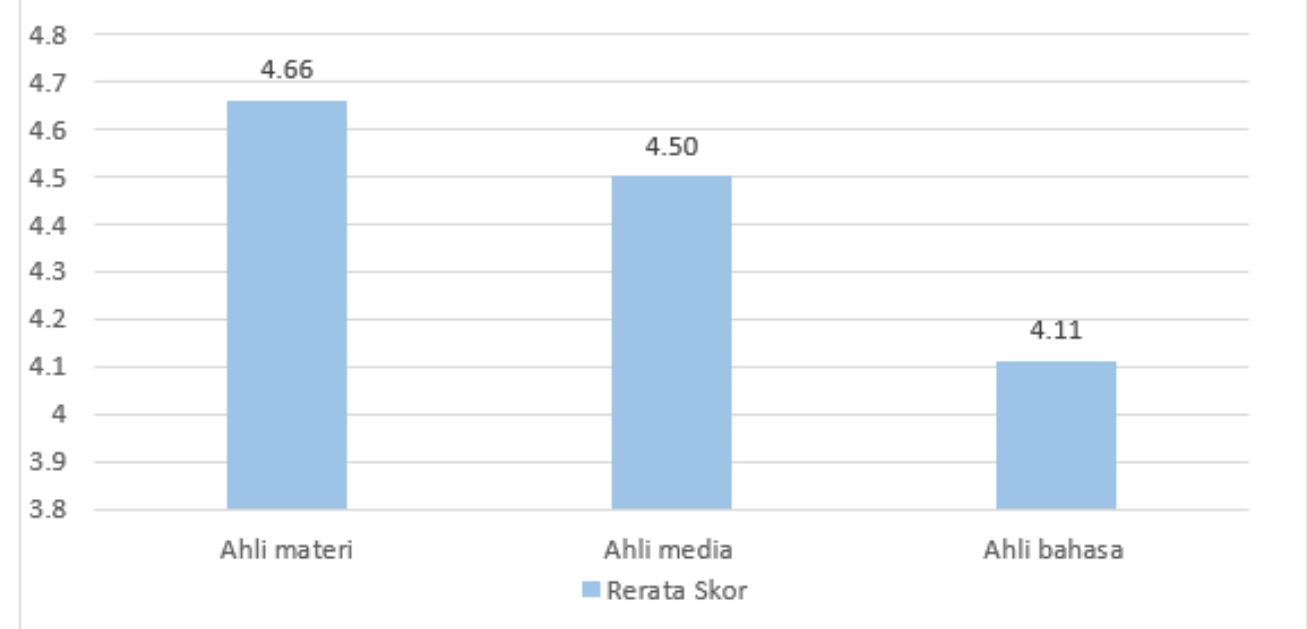

Gambar 1. Rerata Skor Analisis Hasil Validasi Tim Ahli yang Terdiri Atas Ahli Materi, Ahli Media, dan Ahli Bahasa

Ahli materi memberikan beberapa masukan mengenai hal-hal yang perlu diperbaiki dalam media pembelajaran. Berikut revisi yang dilakukan sesuai saran ahli materi, yaitu, memperhatikan isi modul sesuai dengan sintaks JAS (Tabel 1).

\section{Tabel 1}

Revisi dan Hasil Revisi Ahli Materi

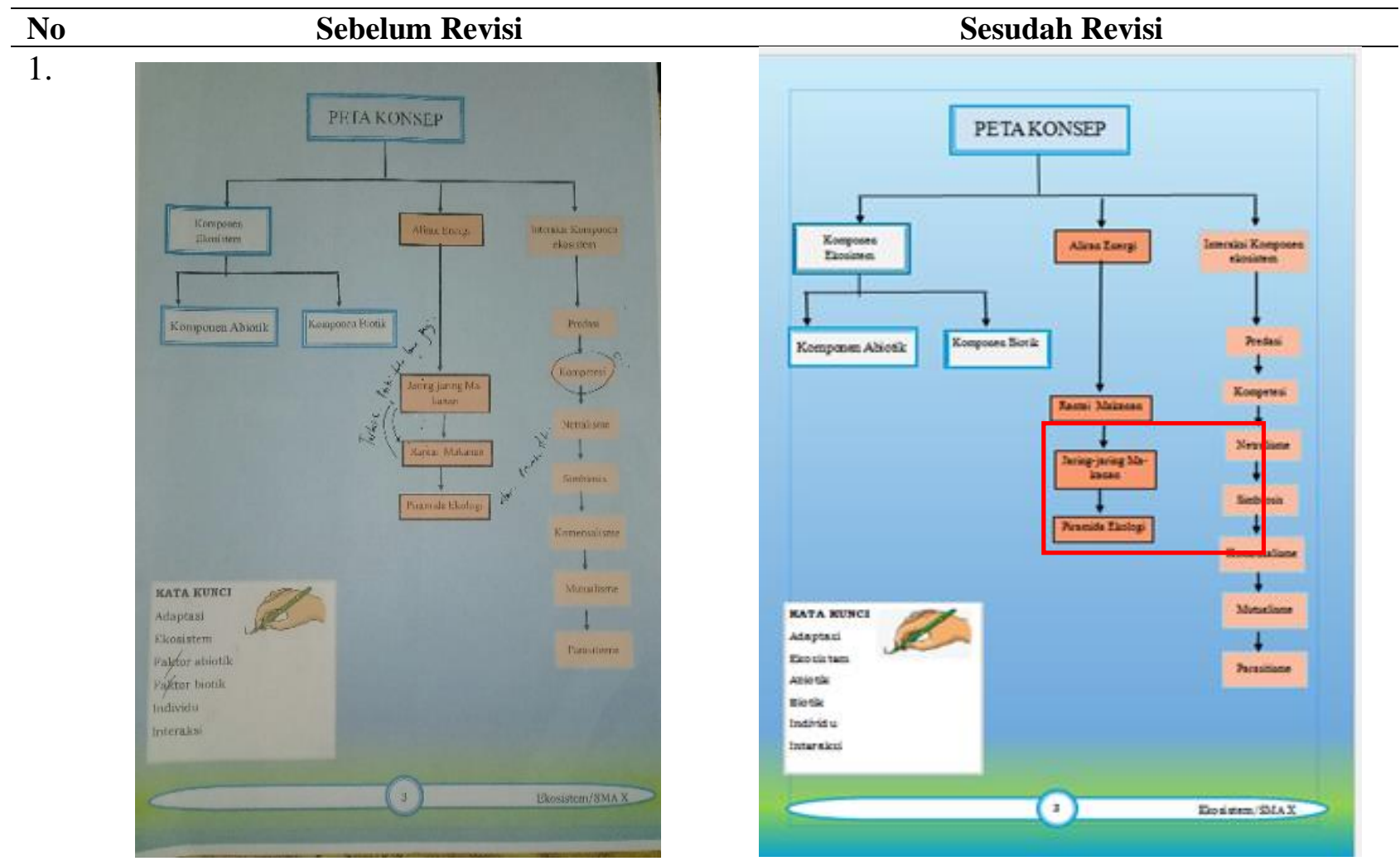



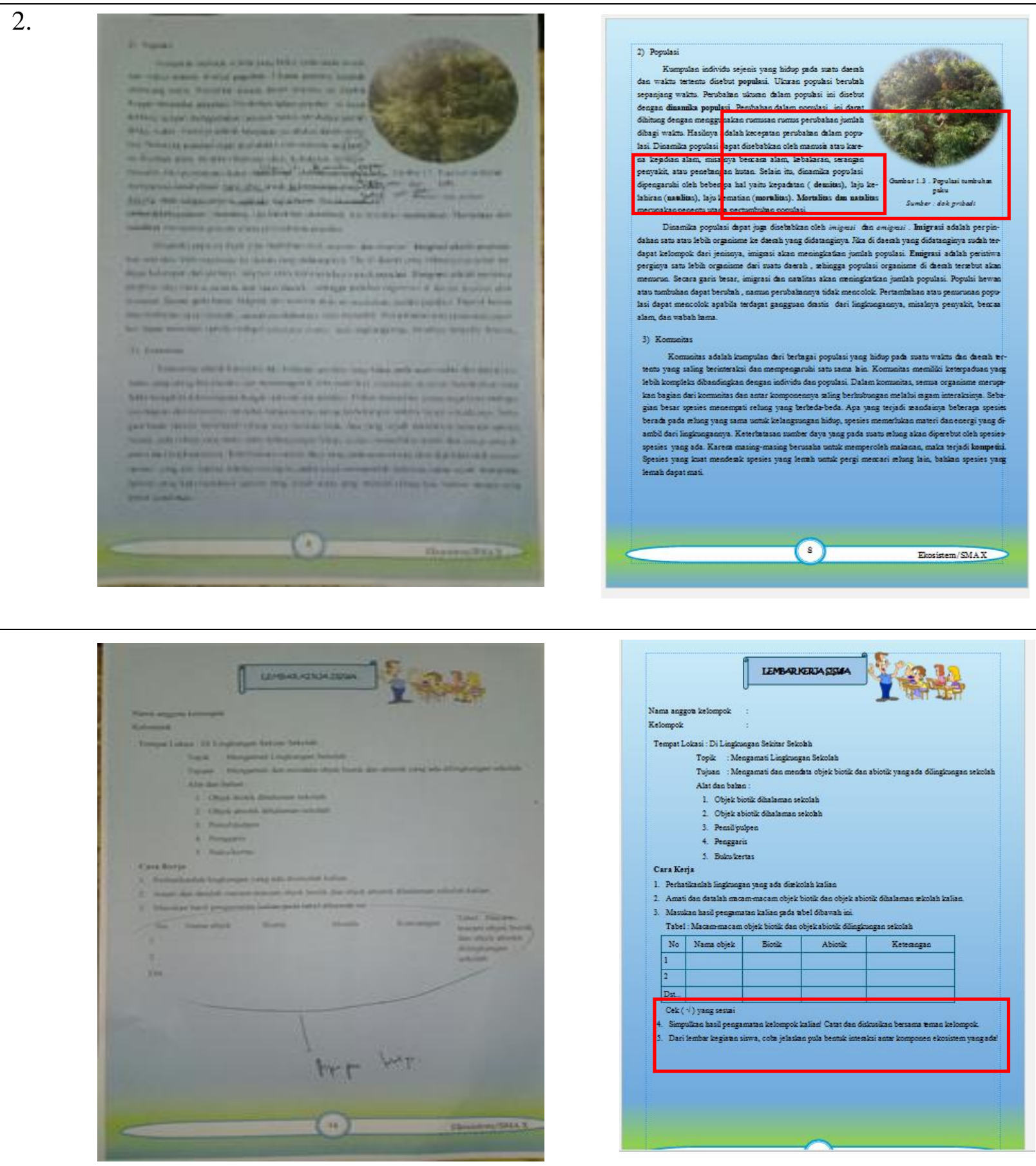

Ahli bahasa memberikan beberapa masukan mengenai hal-hal yang perlu diperbaiki dalam media pembelajaran. Berikut revisi yang dilakukan sesuai saran ahli bahasa, yaitu memperhatikan tata penulisan Ejaan Yang Disempurnakan (EYD) secara benar, menggunakan bahasa yang sesuai (Tabel 2). 
Tabel 2

Revisi dan Hasil Revisi Ahli Bahasa
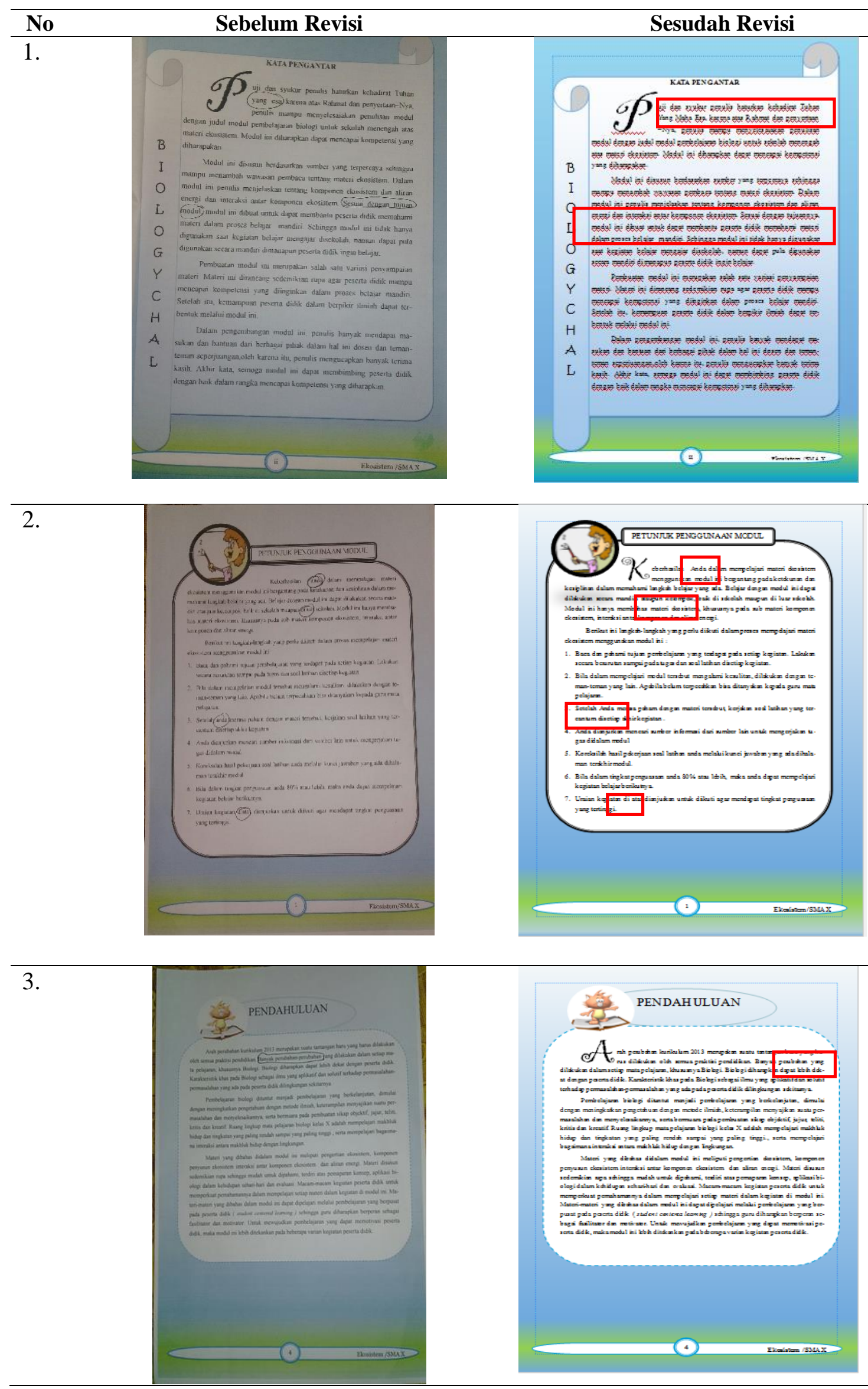


\section{Hasil Uji Skala Kecil dan Revisi II}

Uji coba skala kecil modul biologi berbasis JAS pada materi ekosistem mendapat tanggapan baik dari guru dan peserta didik. Hasil penelitian yang telah dilakukan menunjukkan modul yang dikembangkan dapat dikatakan layak digunakan pada tahap selanjutnya, yaitu uji coba skala besar (Gambar 2). Penilaian ini masuk dalam kategori layak karena nilai yang diperoleh dari angket peserta didik 4,21 dan dari guru biologi 4,0, berada dalam rerata nilai kategori sangat layak (Gambar 2a). Revisi yang dilakukan lebih mengarah kebagian aspek kegrafikan. Hal ini disebabkan karena aspek kegrafikan merupakan salah satu kajian utama dalam meningkatkan pemahaman peserta didik (Bare et al. 2021; Bare \& Sari, 2021).

\section{Hasil Uji Skala Besar}

Analisis data kelayakan skala besar ini melibatkan 24 orang peserta didik dan 2 orang guru biologi dengan katergori layak. Hasil yang diperoleh pada skala besar mengalami peningkatan sebesar 4.39 untuk peserta didik dan 4,11 untuk guru.
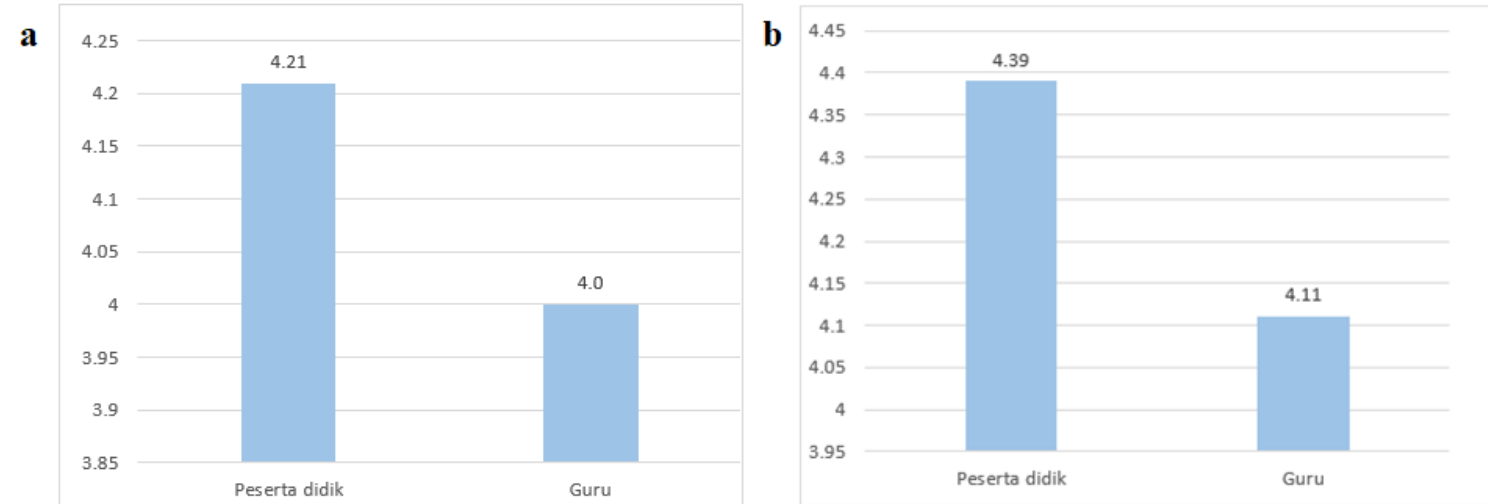

Gambar 2. Rerata Skor Modul Biologi (a) Uji Coba Skala Kecil, (b) Uji Coba Skala Besar

Berdasarkan data yang diperoleh dari tabel di atas, bahwa modul biologi berbasis JAS pada materi ekosistem kelas X SMA mendapat tanggapan positif dari peserta didik dan guru. Hal ini ditunjukkan dengan rerata skor yang diperoleh dan kriteria layak digunakan dalam proses pembelajaran pada materi ekosistem (Gambar 2b). Nilai uji skala sebesar 4.39 untuk peserta didik dan 4,11 untuk guru masuk dalam kategori sangat layak (Gambar 2b).

\section{Kefektifan Modul}

Hasil analisis pelaksanaan tes hasil belajar diperoleh rata-rata nilai pretest sebesar 60,42 dan rata-rata nilai post test sebesar 86,04 (Gambar 3). Hasil tersebut menunjukan bahwa adanya peningkatan hasil belajar peserta didik setelah menggunakan modul yang dikembangan. Peningkatan tersebut juga didukung dengan analisis $\mathrm{N}$-gain sebesar 0,66 yang termasuk dalam kategori sedang. Penelitian terdahulu telah mengembangkan modul yang bertujuan untuk meningkatkan hasil belajar peserta didik. Kelebihan modul dapat menambah pengetahuan siswa secara individu dan kelompok, tidak membosankan, serta meningkatkan kinerja dan pemahaman siswa (Bahri et al., 2016). Kajian Penelitian Ndia et al.,(2021) melaporkan bahwa modul yang dikembangkan akan memiliki nilai $\mathrm{N}$-gain kategori sedang dapat diaplikasikan dalam pembelajaran di sekolah. Selain itu, salah satu kajian yang meningkatkan nilai $N$-gain adalah tampilan modul, hal ini didukung oleh penelitian Bare et al., (2021) menjelaskan media pembelajaran menjadi kunci utama dalam rangka pemahaman berdasarkan studi kasus Implementasi Biology Club. 


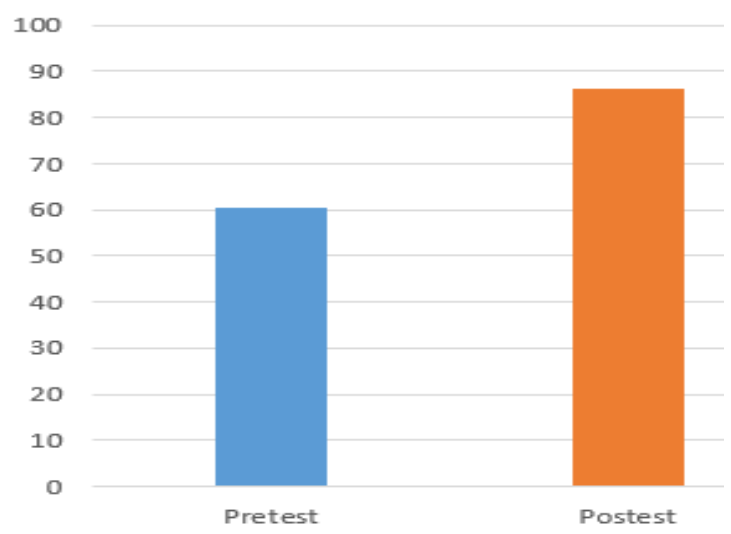

Gambar 3. Nilai Pretest dan Nilai Post Test pada Uji Efektifitas Modul Pembelajaran Biologi

Menurut Hayong \& Putra (2020) pengembangan suatu materi pembelajaran memberikan dampak terhadap proyeksi hasil belajar peserta didik sesuai dengan tujuan yang optimal. Modul memberikan warna baru agar mudah dilakukan selama pembelajaran. Selain itu, siswa dapat melaksanakan kegiatan belajar, bersifat otentik, dan dikembangkan semaksimal mungkin berdasarkan kreativitas setiap peserta didik (Bahri et al., 2016; Sizi et al., 2021).

Kajian Akhir Modul

Produk yang dikembangkan berupa modul biologi berbasis JAS pada materi ekosistem berhasil dikembangkan dan layak digunakan, karena mempunyai beberapa kelebihan, antara lain; 1) Modul biologi berbasis JAS yang dikembangkan memberikan kesempatan kepada peserta didik untuk belajar secara aktif dan mandiri; 2) Modul biologi berbasis JAS yang dikembangkan dapat mengubah kondisi belajar yang pasif (teacher oriented) menjadi aktif (student oriented); 3) Penyajian materi didukung dengan gambar-gambar yang berhubungan dengan materi ekosistem agar dapat memotivasi semangat belajar peserta didik; 4) Modul biologi berbasis JAS dilengkapi dengan info bio, kata kunci, LKS, dan uji kompetensi; 5) Modul biologi berbasis JAS yang dikembangkan sudah menggunakan kurikulum 2013. Aspek implementasi modul dapat dilakukan dengan membawa modul ini dan digunakan dalam pembelajaran di kelas karena didukung oleh nilai yang valid, serta uji kepraktisan masuk dalam kategori sangat layak dengan nilai $N$ gain sedang.

\section{KESIMPULAN}

Modul biologi berbasis JAS pada materi ekosistem studi kasus Taman Nasional Kelimutu (TNK) kelas X SMA dikategorikan layak untuk digunakan. Keefektifan modul biologi berbasis JAS pada materi ekosistem kelas X SMA dilakukan dengan memberikan soal pretest dan post test. Nilai yang diperoleh dari sebelum (pretest) dan sesudah (post test) pembelajaran menggunakan modul biologi yang dikembangkan yaitu 86,04 dengan rata-rata $N$-gain 0,66 dengan kategori sedang. Modul ini sudah layak untuk diaplikasikan sesuai dengan kebutuhan akan tetapi perlu dilakukan modifikasi sesuai dengan kondisi lingkungan belajar peserta didik.

\section{DAFTAR PUSTAKA}

Admadianti, T. (2016). Pengembangan Modul Teknologi Mekanik Untuk Meningkatkan Hasil Belajar Siswa Kelas X Teknik Pemesinan Smk Negeri 3 Buduran Sidoar. Jurnal Pendidikan Teknik Mesin, 5(2).

Bahri, Samsul, Istamar. S., \& Susriyati, M. (2016). Pengembangan Modul Keanekaragaman Hayati dan Virus Berbasis Model Inkuiri Terbimbing Untuk Siswa Kelas X MAN 1 Malang. Jurnal Pendidikan: Teori, Penelitian, dan Pengembangan, 1(2), 10.

Bare, Yohanes et al. (2021). Implementasi Biology Club I di SMA Karitas Watuneso, Kecamatan Lio Timur, Kabupaten Ende. Jurnal ABDINUS : Jurnal Pengabdian Nusantara, 4(2), 32128. 
Bare, Yohanes, \& Sari, D.R.T. (2021). Pengembangan Lembar Kerja Mahasiswa (LKM) Berbasis Inkuiri Pada Materi Interaksi Molekuler. BioEdUIN, 11(1), 8.

Hamalik, Oemar. (2013). Kurikulum dan Pembelajaran. Jakarta: Bumi Aksara.

Hamdani, Hamdani. (2010). Strategi Belajar Mengajar. Bandung: Pustaka Mulia.

Hamidah., Idah., \& Ratnasari, A. (2020). Analisis Kategori Literasi Sains pada Buku Siswa IPA Terpadu SMP/MTs Kelas VIII Semester 1 Kurikulum 2013. Spizaetus: Jurnal Biologi dan Pendidikan Biologi, 1(3), 23-28.

Hardianto. (2012). Belajar dan Pembelajaran. Kampus Universitas Pasir Pangaraian: UPP Press.

Hayong., Mariana, S.W., \& Putra, S. H. J. (2020). Pengembangan Lembar Kerja Peserta Didik (LKPD) Berbasis Inkuiri Pada Materi Sistem Reproduksi Manusia Kelas XI SMA Development of Inquiry-Based Students' Worksheet on Human Reproductive System Subject for $11^{\text {th }}$ Grade Senior High School. Spizaetus: Jurnal Biologi dan Pendidikan Biologi, 1(3), 38-49.

Jayanti., Dwi, U. N. A., Susilo, H., \& Suarsini, E. (2017). Analisis Kebutuhan Bentuk Sumber Belajar dan Media Pembelajaran Biologi Berbasis Potensi Lokal Untuk Kelas X SMA di Provinsi Lampung. Prosiding Seminar Pendidikan IPA Pascasarjana UM 2.

Marianti, A. (2016). Bunga Rampai Pendekatan Jelajah Alam Sekitar (JAS). Semarang: Jurusan Biologi FMIPA UNNES.

Ndia., Xaverius, F., Mago, O. Y. T., \& Bare, Y. (2021). Pengembangan Lembar Kerja Peserta Didik (LKPD) Koopertif Tipe Jigsaw Materi Klasifikasi Makhluk Hidup Kelas VII SMP. Quagga: Jurnal Pendidikan dan Biologi, 13(2), 24-30.

Renat., Epriani, S., Novriyanti, E., \& Armen. (2017). ISSN: 2354-8363 Bioeducation Journal Vol.INo.1-Maret. Bioeducation Journal, 1(1), 14.

Mansur, S., \& Bare, Y. (2019). Meningkatkan Hasil Belajar Siswa pada Konsep Perubahan dan Pelestarian Lingkungan Hidup dengan Model Discovery Learning di SMAS Katolik ST Gabriel Maumere. BIOEDUSCIENCE: Jurnal Pendidikan Biologi dan Sains, 3(2), 84-89.

Santoso., Budi, A., Alimah, S., \& Utami, N. R. (2017). Biological Science Curriculum Study 5e Instructional Model dengan Pendekatan Jelajah Alam Sekitar terhadap Kemampuan Literasi Sains. Journal of Biology Education, 6(2), 14.

Sizi., Yosefina., Bare, Y., \& Galis, R. (2021). Pengaruh Model Pembelajaran Kooperatif Tipe Talking Stick Terhadap Keaktifan dan Hasil Belajar Kognitif Peserta Didik SMP Kelas VIII. Spizaetus: Jurnal Biologi dan Pendidikan Biologi, 2(1), 8.

Sugiyono. 2012. Metode Penelitian Kuantitatif, Kualitatif, dan Kombinasi (Mixed Methods). Bandung: Alfabeta.

2013. Metode Penelitian Pendidikan: Pendekatan Kuantitatif, Kualitatif, dan $R \& D$. Bandung: Alfabeta. 